A N N A L E S

UNIVERSITATIS M A R A E C URIE-SKŁODOW S A

LUBLIN - POLONIA

VOL. LXXIV

SECTIO F

2019

Uniwersytet Zielonogórski

JAROSŁAW KUCZER

ORCID: https://orcid.org/0000-0002-1344-3973

j.kuczer@wpa.uz.zgora.pl

\title{
Struktura dóbr szlacheckich w księstwie głogowskim i podstawy ich prawnego funkcjonowania w czasach habsburskich (1526-1740)
}

Structure of Noble Goods in the Principality of Głogów and the Legal Basis for Their Functioning during the Habsburg Times (1526-1740)

\section{STRESZCZENIE}

W artykule omówiono problem kształtowania się własności ziemskiej w rękach szlachty w okresie habsburskim na obszarze księstwa głogowskiego, pozostającego wydzieloną częścią administracyjną ówczesnego władztwa czeskiego. Poruszono głównie kwestie związane z potencjałem ludnościowym księstwa, z jego terytorium, na bazie czego dokonano analizy rozwoju drobnej, średniej i wielkiej własności ziemskiej. Majątki szlacheckie księstwa głogowskiego powierzane były w posiadanie na podstawie trzech porządków prawnych. Główny podział przebiegał na linii dziedziczności bezwarunkowej, dziedziczności lennej oraz formy przejściowej. U podstaw takiego zróżnicowania leżała skomplikowana historia księstwa głogowskiego tak w środkowym, jak i późnym średniowieczu, a więc jego przynależność do Korony Czech, władania nim przez Piastów głogowskich, a następnie powierzenie go w ręce członków polsko-litewskiej dynastii Jagiellonów (Jana Olbrachta i Zygmunta Jagiellończyka, Władysława Jagiellończyka i Ludwika II). Opisane zróżnicowanie pod względem wielkości majątków i ich pozycji prawnej względem króla Czech związane było z występowaniem tutaj takich form, jak tzw. władztwa, fideikomisy, majoraty i wolne państwo stanowe. Właściciele każdego z nich dysponowali odmiennymi prawami do ziemi, a ich majątki - wraz z podnoszeniem rangi - mogły stać się nawet odrębnymi jednostkami administracyjnymi, których właściciele mogli pozyskać dla siebie prawa równe książęcym (w tym np. osobną pozycję w życiu publicznym przez uzyskanie głosu indywidualnego podczas obrad sejmu śląskiego).

Słowa kluczowe: Śląsk; szlachta; własność ziemska; księstwo głogowskie; fideikomis 


\section{WSTĘP}

Podobnie jak na innych terytoriach Europy Środkowej, tak i na Śląsku w okresie nowożytnym przebiegał proces kumulacji ziem. Dzięki przemyślanej polityce majątkowej część rodzin skupiło w swoich rękach olbrzymie klucze majątków. Należy pamiętać o warunkach właściwych dla Dolnego Śląska, które nie zawsze są porównywalne zarówno z górnośląskimi, jak i czeskimi, a nawet ogólnoniemieckimi. Już siedmio- czy dziesięciowioskowy majątek był traktowany jako podstawa obfitych profitów.

Podstawą utrzymania i egzystencji szlachty głogowskiej była własność feudalna. Aby wejść w posiadanie ziemi, należało legitymować się przynależnością stanową oraz inkolatem danego księstwa, co jeszcze w latach 1713 i 1725 specjalnym patentem potwierdzał Urząd Zwierzchni (Oberamt). W myśl uzasadnienia miało to definitywnie wykluczyć posiadanie ziemi przez nieszlachetnie urodzonych ${ }^{1}$. Charakter własności feudalnej wynikał ściśle zarówno z feudalnego ustroju Śląska, zakładającego posiadanie praw własnościowych nie tylko względem ziemi, lecz także zamieszkujących ją osób, jak i ze zindywidualizowanej zasady, według której wprowadzanie gospodarki czynszowej nie było równoznaczne ze zniesieniem norm wcześniejszych. Akt z 1505 r. sankcjonował przypisanie chłopa do ziemi. Okres habsburski przyczynił się do rozwinięcia rangi, jaką zaczęto nadawać pojęciu „własność feudalna” w praktyce, choć zarazem zaobserwowano równoległy proces ewolucji poddaństwa, który stopniowo przekształcał alodialny folwark w wieś czynszową. To z kolei prowokowało uszczuplanie praw szlachty do ziemi. Jeśli szlachta traciła prawa w zakresie własności, to rekompensowała je sobie krępowaniem wolności poddanych i ich swobody dysponowania ziemią. Druga połowa XVI oraz XVII w. na Śląsku to zdecydowanie okres dominacji gospodarki folwarczno-pańszczyźnianej, co odzwierciedlały ordynacje dotyczące czeladzi i zbiegostwa wydane przez sejm śląski, wśród których wymienia się często te z lat 1623, 1654 i 1679, jak również ordynacje dotyczące porzucania gospodarstw chłopskich z lat 1652 i 1699.

W niniejszym artykule celowo pominięto zagadnienia związane $\mathrm{z}$ dzierżawami królewskimi (tzw. lennami zamkowymi i dobrami zastawnymi), gdyż zostały one omówione w wielu artykułach przyczynkarskich, a z racji swojego charakteru nie były własnością zupełną 2 .

1 Ch. Brachvogel, Continuation derer Käyser- und Königlichen Privilegien, Statuten und Sanctionum Pragmaticum Des Landes Schlesien..., Bd. 3, Breslau 1717-1730, s. 988, Bd. 6, s. 1765.

2 M. Ptak, Lenno zamkowe Żurawina (1608-1615), „Acta Universitatis Wratislaviensis. Prawo" 2001, nr 273, s. 69-85; J. Kuczer, Szlachta jako dzierżawca dóbr królewskich w księstwie głogowskim w XVI-XVII wieku, „Studia Lubuskie” 2007, nr 3, s. 131-145. 


\section{KSIĘSTWO GLOGOWSKIE U ZARANIA EPOKI NOWOŻYTNEJ}

Księstwo głogowskie w granicach z 1526 r. przetrwało do końca XVIII w. Do 1740 r., czyli do momentu przejęcia księstwa przez Królestwo Prus, było całkowitą i pełną jednostką administracyjną. Po tej dacie wprawdzie zniesiono oficjalny podział na księstwa, w zasadzie jednak zachowano ich struktury dla funkcjonowania Rejencji i Kamer Dominialno-Wojennych. Według podziału na księstwa opisywano stan własności państwa czy też budowano koncepcje strategii obronnej. Kiedy w 1526 r. na tron czeski wstąpili Habsburgowie, posiadali oni tytuł książąt głogowskich. To powstałe ok. lat 1249-1251 księstwo z lennego stało się dziedzicznym, a więc przypisanym bezpośrednio tytułowi królewskie$\mathrm{mu}^{3}$. Punktem zwrotnym w jego historii była tzw. wojna o sukcesję głogowską, zakończona traktatem zawartym w Kamieńcu Ząbkowickim z 1482 r. Henryk XI $\mathrm{z}$ dynastii Piastów śląskich był ostatnim władcą lennym ${ }^{4}$.

Potencjał księstwa głogowskiego był jednym z najwyższych na Śląsku. Było to jedno z najbogatszych księstw, o największym potencjale ludnościowo-gospodarczym. Terytorialnie ustępowało wyłącznie księstwom opolsko-raciborskiemu i świdnicko-jaworskiemu, a więc księstwom tzw. podwójnym. Dla okresu nowożytnego szacuje się, iż obejmowało $82,80 \mathrm{mil}^{2}\left(4559 \mathrm{~km}^{2}\right)$. Składały się na nie jednostki administracyjne, które określano mianem weichbildu. W początkach XVI w. były to weichbildy: kożuchowski, świebodziński, głogowski, zielonogórski, górowski, polkowicki, szprotawski ${ }^{5}$. Największą powierzchnię miał weichbild głogowski, który wchłonął uległy likwidacji ok. 1638 r. weichbild polkowicki ${ }^{6}$.

Pierwszy spis ludności z 1577 r., który zaprezentował Władysław Dziewulski, podał liczbę 14921 osób osiadłych w księstwie. Nie posiadamy analogicznych informacji dla XVII w., lecz wiemy, iż w wyniku wojny trzydziestoletniej (1618-1648) miejscowa demografia się załamała. Wyjątkiem może być niepełny

3 I.G. Sternagel, Geschichte Schlesiens, Breslau 1803, s. 54-55; M. Weber, Das Verhältnis Schlesien zum Alten Reich in Früher Neuzeit, Köln 1992, s. 74-75; J. Bahlcke, Regionalismus und Staatsintegration im Widerstreit. Die Länder der böhmischen Krone in ersten Jahrhundert der Habsburgerherrschaft (1526-1619), Mümchen 1994, s. 45; T. Jurek, Geneza księstwa glogowskiego, „Przegląd Historyczny” 1987, nr 78, s. 79-92.

4 Scriptores Rerum Silesiacarum, hrsg. von H. Markgraf, „Annales Glogovienses bis zum Jahr 1493 nebst urkundlichen Beilagen“ 10, Breslau 1877, s. 106; H. Szczegóła, Z dziejów księstwa głogowskiego w wiekach średnich, [w:] Ze studiów nad średniowiecznym Głogowem i Krosnem, Zielona Góra 1970, s. 136.

5 Por. A. Gryphius, Glogauisches Fürstenthumbs Landes Privilegia aus dem Originalen an tag gegeben..., Lissa 1653, s. 8.

6 M. Ptak, Zgromadzenia i urzędy księstwa głogowskiego od poczatku XIV w. do 1740 r., Wrocław 1991, s. 26-27. 
spis z 1619 r. ${ }^{7}$ Ujęcie spoza końca omawianego okresu, czyli spis z 1787 r., na którym oparł się Friedrich Zimmermann w swoim opisie księstwa głogowskiego, również nie było precyzyjne ${ }^{8}$. Śmielsze omówienie problemu znajduje się w badaniach Mariana Ptaka, który ustalił liczbę mieszkańców księstwa na 137 tys. Autor dokonał tego poprzez interpretację metody szacunkowej. Przyjął, że pierwotna liczba ponad 14 tys. osób dotyczyła wyłącznie posesjonatów. Dziś już wydaje się, że była to słuszna droga i założenie, ponieważ wiemy, że w ówczesnych spisach wymieniano jedynie osoby posesjonatów, na których barkach spoczywał obowiązek wojskowy. W związku z tymi szacunkami w $1577 \mathrm{r}$. zaludnienie księstwa sięgało 30 osób na km², a w 1787 r. - 37 osób na km². W związku z tym księstwo było również na trzecim miejscu pośród księstw śląskich pod względem zaludnienia9.

Księstwo głogowskie nie było jednolite pod względem terytorialnym. Z jego ziem podstawowych wyłączone były dwie enklawy: weichbild świebodziński oraz okręg chobieński (należący do weichbildu górowskiego). W 1686 r. miało miejsce czasowe przekazanie weichbildu świebodzińskiego margrabiemu Brandenburgii. $\mathrm{Z}$ jego terytorium utworzono nawet osobne księstwo. Wskutek protestu stanów księstwa głogowskiego weichbild został zwrócony w 1695 r. drogą wykupu. Ponadto z dóbr księstwa głogowskiego już w 1616 r. (a ostatecznie w 1697 r.) zostało wydzielone tzw. Wolne Państwo Stanowe (Freiestandesherrschaft Carolath-Beuthen), należące do rodziny von Schönaich. Wolne Państwa Stanowe formalnie posiadały status księstw, a ich właściciele byli „,panami na miarę książęcą”. Były to rodzaje ordynacji ziemskiej, ich właściciele cieszyli się uprawnieniami przynależnymi na Śląsku stanowi książęcemu ${ }^{10}$.

Uprzywilejowaną pozycję wśród właścicieli ziemskich księstwa głogowskiego posiadali, co naturalne dla omawianego okresu, szlachcice. Poświadczały to już przywileje z lat 1508-1513 nadane przez Jagiellonów. Ostatecznie przypieczętowały one prawo nieskrępowanego obiegu lenn w rękach jednego stanu, podobnie jak w Królestwie Polskim, odbierając tę możliwość mieszczaństwu. Ostatecznie taki stan rzeczy zatwierdził król czeski Ferdynand I Habsburg aktem z dnia 7 marca 1552 r. Dokument zezwalał szlachcie śląskiej na „wolną sprzedaż, zastaw i czynienie nadań z dóbr własnych na dotychczasowych warunkach"11.

7 W. Dziewulski, Zaludnienie Śląska w końcu XVI w. i na początku XVII w., „Przegląd Zachodni” 1952, nr 8, s. 419-492; idem, Nowe dane statystyczne o ludności miast $i$ wsi Ślaska w XVI w., „Śląski Kwartalnik Historyczny Sobótka” 1975, nr 30, s. 457-474.

8 F. Zimmermann podał liczbę 171256 mieszkańców księstwa głogowskiego. Zob. F. Zimmermann, Bayträge zur Beschreibung von Schlesien, Bd. 10, Brieg 1791, s. 5.

9 M. Ptak, Zgromadzenia i urzędy ..., s. 29.

10 F. Zimmermann, op. cit., s. 6; G. Zerndt, Geschichte von Stadt und Kreis Schwiebus, Bd. 2, Schwiebus 1909, s. 344-349; C. Grünhagen, Geschichte Schlesiens, Bd. 2, Gotha 1884, s. 362-369; Z. Kaczmarczyk, Dzieje Ziemi Lubuskiej, „Rocznik Lubuski” 1981, t. 11, cz. 1, s. 49.

11 F. Minsberg, Geschichte der Stadt und Festung Gross-Glogau, Bd. 2, Glogau 1853, s. 21. 
Nie można zapominać, że wśród dóbr szlacheckich i szczególnie nielicznych miejskich-korporacyjnych znajdowały się majątki domeny książęcej, a później królewsko-cesarskiej (tak były określane w dokumentach). Od XIV w. znajdowała się ona w regresie spowodowanym licznymi nadaniami dla rycerstwa, w tym wielkich rodów ministeriałów, jak Gersdorf, Rechenberg, Knobelsdorff, Kalckreuth, Haugwitz itd. Książęta pozyskiwali tym samym w prosty, choć karkołomny sposób drogo opłacaną armię. W związku z tym tutejsza domena była jedną z najbardziej rozdrobnionych i najmniejszych pośród domen innych księstw. Według spisu z $1681 \mathrm{r}$. składała się zaledwie z siedmiu majątków, które były położone $\mathrm{w}$ weichbildzie kożuchowskim. Ich zarząd oddano w ręce Urzędu Kameralnego (Cammeramt) w Nowej Soli. Istniały jeszcze cztery majątki zamkowe podległe staroście jako najwyższemu reprezentantowi władzy królewskiej w księstwie. Dochody z nich pozostawały w jego gestii i były wydatkowane na potrzeby prowadzenia urzędu oraz generalnego zaopatrzenia zamku jako jego siedziby ${ }^{12}$.

W związku z powyższym widać, do jakiego stopnia szlachta, posiadająca również miasta prywatne, zyskała niemal całkowitą przewagę nad innymi stanami. Prawo do posiadania ziemi określano mianem rycerskiego (Ritterrechtgut). Szlachtę głogowską w dokumentach określało się początkowo jako Ritter, a następnie zamiennie z Adel. Ostatecznie do tej grupy już na stałe w XVI w. dołączyły elity możnowładców zwanych „panami” (Herren). Byli to zarówno baronowie (Freiherren), jak i hrabiowie (Grafen). Ci ostatni pojawili się ok. połowy XVII stulecia.

\section{POPULACJA SZLACHTY KSIĘSTWA GŁOGOWSKIEGO}

Na przełomie XVII i XVIII w. śląski kronikarz i najwyższy fiskał Górnego i Dolnego Śląska - Johann Sinapius - określił liczbę posiadaczy szlacheckich w prowincji na 3000, co można traktować jako pewną generalizację ${ }^{13}$. Księstwo głogowskie leżało w tzw. trzecim okręgu obrony terytorialnej. Dla samego księstwa głogowskiego podał ją spis z $1577 \mathrm{r}$. Według tego źródła były to 233 osoby, co stanowiło 1,6\% wszystkich osiadłych. Przy przyjęciu współczynnika 5-6 (sugerowanego przez M. Ptaka) oraz oparciu się na spisie z 1787 r., w którym liczbę mężczyzn traktować będziemy jako liczbę posesjonatów księstwa, otrzymujemy obraz, w którym ogólna liczba szlachty w księstwie głogowskim nie przekraczałaby 1200-1400 osób. Kolejny spis, pochodzący z 1671 r., wskazywał 655 posesjonatów, co mogło

12 Archiwum Państwowe we Wrocławiu (dalej: APW), Księstwo głogowskie 1329-1886, Rep. 24, sygn. 135, s. 67-74, sygn. 155, s. 8-24, sygn. 513, Rubrika 4 i 5; Codex Diplomaticus Silesiae, t. 24, s. 112 (dalej: CDS).

13 J.C. Sinapius, Schlesien in merkantilischer, geographischer und statistischer Hinsicht, Sorau-Leipzig 1806, s. 149. 
szacować liczbę szlachty na przynajmniej $3000^{14}$. U schyłku omawianej epoki liczba ta spadła. W $1718 \mathrm{r}$. w księstwie głogowskim zanotowano 186 właścicieli. Było to odpowiednio $80 \mathrm{w}$ weichbildzie głogowskim, 32 - górowskim, 25 - świebodzińskim, 18 - kożuchowskim, 20 - zielonogórskim, 11 - szprotawskim ${ }^{15}$. Przyjmując powyższy współczynnik, można założyć, że księstwo było zamieszkiwane wówczas przez 900-1200 osób tego stanu. Tendencja spadkowa została potwierdzona przez spis z 1787 r., w którym znajdujemy już liczbę 832 osób ${ }^{16}$. Analiza kolejnych spisów dóbr wskazuje, że mniejsze majątki skupiane były w rękach arystokracji, zarówno śląskiej, jak i cudzoziemskiej, przybyłej tu po wojnie trzydziestoletniej. Była to konsekwencja nadawania ziem i tytułów arystokracji i szlachcie, wiernym polityce dworu królewsko-cesarskiego, często katolickich generałów, najwyższych urzędników i dygnitarzy kościelnych. Liczbę osób w księstwie mógł zaniżać również inny istotny czynnik. Był nim fakt, iż niezamężne kobiety, wdowy i tzw. pupile (nieletni poniżej 12. roku życia) byli zazwyczaj reprezentowani przez posesjonatów męskich tak w spisach, jak i podczas obrad sejmikowych. Zazwyczaj byli to sąsiedzi bądź męscy członkowie rodziny, posiadający dobra także w księstwie ${ }^{17}$.

Skomplikowana szachownica dóbr o dwo-, a nawet trojakim statusie powodowała pewne zamieszanie. Dla ich sklasyfikowania i rejestracji powoływano specjalne komisje. Świadczy o tym przykład z 1681 r., kiedy do składu takiego gremium, obradującego przez ponad rok, dokooptowano archidiakona kapituły głogowskiej Philippa Jacoba de Cuba oraz niejakiego „posługującego” Daniela Thalerera von Canona wraz z miejscową szlachtą. Poszczególne weichbildy odpowiednio reprezentowali: głogowski - Wolff Alexander von Stosch na Białej Wodzie i Wolff von Popschütz; kożuchowski - Otto von Glaubitz na Urzutach i Gotthard von Dyhern na Mirocinie Górnym; górowski - Ernst Gottfried von Diebitsch na Naratowie i Wenzel Wilhelm von Haugwitz na Sicinach; szprotawski - Christian Heinrich von Berge na Suchej i Otto von Skopp na Przecławiu; zielonogórski - Hans von Nostitz na Świdnicy i Balthasar von Unruh na Zatoniu; świebodziński - Friedrich Christian von Handorff na Szczańscu i Balthasar von Dyhern na Jeziorach (?). Całości patronował hrabia von Herberstein, starosta

14 N. Henelius, Silesiographia renovata necessariis Scholiis observationibus et indice aucta, Wratislaviae-Lipsiae 1704, Cap. XII, s. 1151; H.L. Gude, Staat von Schlesien, Halle 1708, s. 423; J.S. Schickfuss, New vermehrte Schlesische Chronika und Landesbeschreibung bis 1619, JenaBreslau 1625, ks. 3, s. 238.

15 APW, Księstwo głogowskie 1329-1886, Rep. 24, sygn. 527, s. 7-24; W. Dziewulski, Nowe dane statystyczne..., s. 455-477. Por. M. Ptak, Zgromadzenia i urzędy ..., s. 34-37.

16 Generalne tabele statystyczne Śląska 1787 roku, wyd. T. Ładogórski, Wrocław 1954, s. 98 100, 274-277.

17 Publicznie pupile i kobiety reprezentowani byli przez wyznaczanych opiekunów. W szczególnych przypadkach opiekunem mógł być szlachcic nieposiadający indygenatu głogowskiego. W 1549 r. opiekunem Barbary von Rechenberg był Wojciech Leszczyński, właściciel Leszna i jednocześnie jej małżonek. Zob. CDS, t. 24, s. 85-86, nr 95; Ch. Brachvogel, op. cit., Bd. 3, s. 930. 
księstwa pochodzący z Austrii1 ${ }^{18}$. Dokładną liczbę ogółu szlachty osiadłej na ziemi określił dopiero spis z $1787 \mathrm{r}^{19}$

Tabela 1. Liczba szlachty osiadłej na ziemi w poszczególnych powiatach

\begin{tabular}{|c|c|c|c|c|c|}
\hline Powiat & Mężczyźni & Kobiety & Synowie & Córki & Razem \\
\hline Głogowski & 44 & 41 & 35 & 53 & 173 \\
\hline Kożuchowski & 19 & 20 & 17 & 12 & 68 \\
\hline Górowski & 19 & 19 & 18 & 10 & 66 \\
\hline Świebodziński & 13 & 13 & 9 & 26 & 61 \\
\hline Zielonogórski & 10 & 11 & 10 & 11 & 42 \\
\hline Szprotawski & 6 & 8 & 8 & 7 & 29 \\
\hline Razem & 111 & 112 & 97 & 99 & 439 \\
\hline
\end{tabular}

Źródło: Generalne tabele statystyczne Śląska 1787 roku, wyd. T. Ładogórski, Wrocław 1954, s. 274-277.

Z początkiem migracji rycerstwa na Śląsk, a tym samym najpierw do księstw głogowskiego i świdnicko-jaworskiego, starało się ono zapewnić sobie rzetelne podstawy materialne. Trzeba pamiętać, że odległość od Łużyc, Turyngii czy Saksonii była niewielka, dlatego część rycerstwa przebywała tu jedynie czasowo. Po zgromadzeniu odpowiednich środków wracano inwestować w swoich ziemiach. Większość jednak decydowała się pozostać. Otrzymawszy nadanie ziemskie, rycerz starał się drogą kupna pozyskać dobra chłopskie i utworzyć namiastkę późniejszej gospodarki folwarcznej. W przyszłości sposób bogacenia się i zdobywania areału był zbliżony do analogicznych działań prowadzonych przez szlachtę w całej Europie Wschodniej. Chodzi głównie o profity czerpane z zawierania korzystnych układów matrymonialnych, wykupywanie dóbr podupadłych czy sukcesywne skupowanie sąsiednich wsi oraz przemyślane scalanie ich części w jedną całość (tzw. zaokrąglanie) ${ }^{20}$.

\section{PRAWO RYCERSKIE DO ZIEMI}

Szlachta w księstwie głogowskim posiadała majątki na podstawie dwóch typów własności, co było pozostałością czasów wcześniejszych („polskich”). Były to dobra alodialne oraz dobra lenne. Alodia łączono z nadaniami na pra-

18 APW, Księstwo głogowskie 1329-1886, Rep. 24, sygn. 382, s. 392.

19 Generalne tabele statystyczne..., s. 274-277.

$20 \mathrm{Na}$ stosowanie takiej metody może wskazywać analiza archiwaliów zgromadzonych w Österreichisches Staatsarchiv. Potwierdza ona, że właściciele dóbr szlacheckich najczęściej wchodzili w związki małżeńskie z pannami i wdowami zamieszkującymi księstwo głogowskie, a dopiero w drugiej kolejności z osobami spoza księstwa. Zob. Österreichisches Staatsarchiv (dalej: ÖS), Finanz- und Hofkammer Archiv (dalej: FHA), Familien-Akten, B/P 442, C/K 1-19, 263 i 264 , D-T 176, D 81, G 190, H - 22 i 44, L 86, R 44, S 54, 185, 195, 308 i 384, Z 18. 
wie tzw. polskim. Były one podległe sądom czudowym, a więc nie bezpośrednio monarsze jako księciu. Automatycznie były również własnością dziedziczną, podczas gdy ziemie na prawie „niemieckim” były nadawane głównie od końca XV w., choć znane były już wcześniej z uwagi na kolonizację księstwa przez rycerstwo niemieckie i przenoszenie tamtejszych norm prawnych na Śląsk ${ }^{21}$.

W okresie nowożytnym wcześniejsza przynależność państwowa, zacierająca się zresztą, nie miała już znaczenia, gdyż nadawano wyłącznie lenna na prawie niemieckim. Każdorazowy spadek bądź przejęcie w wyniku polityki matrymonialnej musiało być potwierdzone przez króla Czech, będącego w większości przypadków również cesarzem rzymskim i królem niemieckim. Ze zderzenia obu form powstała forma trzecia. Było to możliwe dzięki pojawieniu się cech zbieżnych, jak np. obowiązek składania hołdu lennego każdorazowemu księciu przez szlachtę osiadłą na dobrach obu rodzajów. Należy zaznaczyć, że przez cały okres habsburski majątki czudowe występowały głównie w weichbildach głogowskim i górowskim, gdzie zyskały przewagę nad dobrami lennymi. W pozostałych relacja ta miała odwrotny charakter ${ }^{22}$.

Możliwa była więc także zamiana podstawy prawnej własności gruntowej. Było to związane z przechodzeniem lenn we własność dziedziczną typu alodialnego. Dysponujemy dziś licznymi przykładami potwierdzającymi taki stan rzeczy. Z lennego w alodialne uległ zmianie charakter rozległego klucza ziemskich majątków Chobieni i Brodowic z końcem XVII w., a jeszcze w 1608 r. aktem Rudolfa II - Zatonia, pozostającego wówczas w rękach Sigmunda von Kittlitza ${ }^{23}$. $\mathrm{Z}$ czasem królowie coraz rzadziej godzili się na taką zmianę. Dość dobrze ilustruje to przykład Georga von Schönaicha, którego wieloletnie zabiegi o przejęcie schedy po zmarłym Fabianie zakończyły się wprawdzie 1 lipca 1595 r. sukcesem, lecz zostały okupione wysokimi sumami wypłaconymi zausznikom na dworze wiedeńskim oraz potwierdzoną sumą 110 tys. rtl. wniesioną do skarbu cesarskie$\mathrm{go}^{24}$. W latach 1681-1755 charakter zmieniły również majątki w weichbildzie

${ }^{21}$ J. Schickfuss, op. cit., s. 97-98; S. Nowogrodzki, Rzady Zygmunta Jagiellończyka na Ślasku i w Łużycach, Kraków 1937, s. 42 i 44; H. Aubin, Geschichte Schlesiens, Bd. 1, Breslau 1938, s. 285; G.A. Stenzel, Geschichte Schlesiens, Breslau 1853, s. 268-269; Z. Wojciechowski, Ustrój polityczny Śląska, [w:] Historia Śląska od najdawniejszych czasów do roku 1400, t. 1, Kraków 1933, s. 666-667. Określenia „alodium” w prawodawstwie polskim doby średniowiecza używano w stosunku do majątków folwarcznych. Por. R. Heck, Uwagi o gospodarce folwarcznej, „Śląski Kwartalnik Historyczny Sobótka” 1956, nr 11, s. 170.

22 M. Ptak, Zgromadzenia i urzędy..., s. 31-33.

${ }^{23}$ CDS, t. 24, s. 87, nr 113.

24 Cesarz chwilowo dopuścił się złamania danego Schönaichowi prawa na rzecz Melchiora von Rechenberga, a dobrami późniejszego majoratu kupczono nawet na sejmie śląskim. Zob. C.F. Michaelis, Rechtliche und Historische Entwicklung der Verhältnisse der Lehn- und Fidei-Commis-Herrschaften Amtitz und Möllendorf und Rechte des jedesmaligen regierenden Fürsten zu Carolath-Beuthen auf dieselben, Glogau 1832, s. 6; H. Hoffmann, Fürst Carolath contra Glogau- 
kożuchowskim: Stypułów, Mirocin Dolny, część Studzieńca, Lelechów Knobelsdorffów. Z kolei w weichbildzie szprotawskim były to Henryków oraz położony w niewielkiej odległości od Polkowic, nieistniejący już dziś Neudeck markiza de Varenne ${ }^{25}$.

Dla okresu od XVI do XVII w. nie mamy bezpośrednich danych na temat ewentualnego kredytowania transakcji kupna-sprzedaży. Nie wiemy też, czy szlachta stawiała się w roli kredytodawcy, a więc czynnie. Jako nieetyczne zajęcie, kojarzone $\mathrm{z}$ lichwą, było ono stosowane jedynie w odniesieniu do dworu cesarskiego. Szlachta niejednokrotnie dzierżawiła dobra na określony czas. W rzeczywistości wiele z nich pozostało już w rękach przybyszów. Można zaryzykować stwierdzenie, że skarb królewsko-cesarski był niemal zawsze niewypłacalny. Zastaw dotyczył również domen kameralnych oraz ceł, myt itd. Jesteśmy dziś w stanie wymienić setki obligacji wystawianych tutejszej szlachcie przez urząd starościński oraz bezpośrednio przez kancelarię cesarską ${ }^{26}$. Spadkobranie nierzadko prowadziło do przelewu krwi i swego rodzaju ,śląskich zajazdów". I tak tworzone były większe majątki, kompleksy i klucze ziemskie. Paradoksalnie przechodzenie dóbr z rąk do rąk doprowadziło w niektórych weichbildach (zwłaszcza zielonogórskim) do rozdrobnienia, a nawet do znanego w Polsce podziału wsi, w których notowano do czterech właścicieli łącznie. Tak powstała właśnie znana na Dolnym Śląsku ,szlachta cząstkowa” (Partielladelige, Teilposessionaten). Podziały mogły przebiegać w jednej rodzinie lub nawet w kilku; na ich terenie budowano odpowiednią liczbę siedzib szlacheckich (Ritterschloss ${ }^{27}$. Planowanie podziału dóbr wymagało zgody władz. Z intencjami rozdrobnienia szlachta musiała zwracać się do Urzędu Starościńskiego w Głogowie, a po 1740 r. i zajęciu Śląska przez Prusy - do Rejencji Głogowskiej. Bywało też tak jak w 1661 r., kiedy to fiskał królewski Kaspar Alexander Menniche odmówił w imieniu króla rodzinie Dyhern podziału klucza dóbr Zabór. Ponieważ nie udało się Dyhernom utrzymać majątku, w przyszłości przejmowali go zausznicy cesarscy (Dünnewald, Pachta, Sintzendorf), którzy bądź zasługami,

er Jesuiten, Ein Beitrag zur Friderizianischen Kabinettsjustiz, „Archiv für Schlesische Kirchengeschichte“" 1936, Bd. 1, s. 168.

25 Spisu dokonano na życzenie i zaadresowano do kancelarii ministra śląskiego hrabiego Ludwika Wilhelma von Münchowa z dnia 3 kwietnia 1753 r. Zob. APW, Księstwo głogowskie 13291886, Rep. 24, sygn. 513.

26 Przytoczyć tu można dokumenty z 1608 r. wystawione zawierzającemu na rok 8000 rtl. Sigmundowi von Kottwitzowi na Konotopie, dalej dokumenty dla Hansa von Unruha - składającego 3500 rtl., czy Georga von Kreckwitza, który pożyczywszy 3500 rtl., miał otrzymywać raty obciążone rocznym czynszem $6 \%$ zabezpieczonych na podatkach odciąganych z miast weichbildowych księstwa głogowskiego. Zob. ÖS, FHA, Böhmische Gedenkbücher, Bd. 31, s. 201-202, 204, 253-254.

27 H. Aubin, op. cit., s. 285; W. Barth, Die Familie von Schönaich und die Reformation, Beuthen 1891, s. 27. 
bądź drogą finansowania skarbu pozyskiwali Zabór dla siebie. Jak się jednak okazywało, ten sposób gromadzenia dóbr nie był stabilny ${ }^{28}$.

Harmonia stosunków pomiędzy właścicielami dóbr w jednej wsi czy nawet miasteczku prywatnym była zbudowana na bazie umów kompetencyjnych oraz na obopólnym respektowaniu praw zwyczajowych. Interesująco rzecz się miała w mieście prywatnym Nowe Miasteczko, gdzie w 1484 r. spisano zasady patrymonialne i ekonomiczno-jurydyczne pomiędzy rodziną von Tauchsdorfów, która posiadała jeden nadział, a rodziną von Berge, będącą w posiadaniu trzech kolejnych. Układ obowiązywał do początku XVII w. Dokument traktował o sposobie zapobiegania sporów oraz o sąsiedzkiej przychylności względem siebie. Ponadto znajdowały się w nim zapisy dotyczące prawa do wspólnego korzystania z młyna czy o oddzielnym sądownictwie w każdym z majątków. Co ciekawe, były one różne dla osób mieszkających w miasteczku oraz dla osób przybywających z zewnątrz. Kwestię wyboru burmistrza rozwiązano w ten sposób, że Bergowie powoływali na to stanowisko radnego na trzy lata (wybory odbywały się co roku), natomiast w czwartym roku czynili to Tauchsdorfowie, a w przyszłości - Rechenbergowie. Bergowie wybierali też po trzech radnych oraz ławników i przysięgłych (Gäschworene) jako przedstawicieli starszyzny cechowej. Z kolei Tauchsdorfowie jedynie po jednym z każdej grupy, ze swojej części majątku. Osobom wyłonionym w ten sposób na urzędy nakazywano złożenie przysięgi, iż będą mieli na sercu "dobro i godność miasta”. W umowie postanowiono pójść na ustępstwa w kwestii zaokrąglenia nadziałów. Również według ilości nadziałów (czyli „trzy do jednego”) pobierano opłaty targowe i inne podatki związane z funkcjami gospodarczymi. Ważnym postanowieniem było ograniczenie rozlewu piwa ważonego poza granicami miasta, podobnie sprawa miała się z winem. Poza ustalonymi terminami każda ze stron ustalała, że będzie zapobiegać nielegalnemu procederowi, a sprzedawane produkty będą wyłącznie pochodzenia miejskiego. Ponadto ustalono, że każda strona będzie miała prawo do korzystania ze stawu jako wodopoju dla bydła. Otwarte pozostały trakty hodowlane prowadzące do wodopoju - bez względu na to, po czyjej ziemi biegły. Dodatkowo stwierdzono, że każda pominięta w umowie sprawa będzie traktowana według istniejącego „zwyczaju ojców”, a spory będą rozstrzygane sądownie. Dokument sygnowali bracia Kaspar, Balzer i Christoph von Tauchsdorf oraz Kaspar i George von Berg. Mimo że w 1506 r. dobra nowomiejskie Tauchsdorfów nadano Rechenbergom, a Bergów od 1537 r. zastąpili Knobelsdorffowie i Haugwitze, dokument z pewnymi modyfikacjami nadal obowiązywał ${ }^{29}$.

28 Archiwum Państwowe w Zielonej Górze (dalej: APZG), Majątek Zabór, sygn. 8, s. 3.

29 G. Jokisch, Geschichte der Stadt Neustädtel, Glogau 1866, s. 24-26; O. Heller, Der Freitädter Kreis mit besonderer Berücksichtigung des Fürstentums Carolath-Beuthen in geographisch-statistischer und geschichtlicher Beziehung, Freystadt 1844, s. 58-61; E. Kolbe, Geschichte der Stadt Neustädtel, unter Benutzung amtlicher und privater Quellen bearbeitet, Neustädtel [po 1924 r.], s. 45-47 i 195. 
Analogiczne ustalenia dotyczyły majątków Letnica i Dobra w weichbildzie zielonogórskim. Jako właściciele występowali tutaj Keßlitzowie dwóch linii rodowych. Dokument datowano na 20 grudnia 1601 r. Ustalał on szczegółowo przynależność każdego z elementów gospodarki wiejskiej, ich przeznaczenie i powinności poddanych względem panów, prawa do sądownictwa wyższego i niższego. Rozstrzygnięto wówczas także - co szczególnie interesujące - kwestie patronatu nad miejscowym kościołem. Odpowiedni dokument jeszcze przed wojną miał być przechowywany w archiwum majątku, który dziś uznaje się za zaginiony ${ }^{30}$.

\section{ROZDROBNIENIE MAJĄTKOWE. DROBNA WŁASNOŚĆ ZIEMSKA}

Rozdrobnienie majątkowe dóbr szlacheckich księstwa głogowskiego dość dobrze przedstawia analiza struktury majątków w weichbildzie zielonogórskim. Mieliśmy tu zarówno dobra cząstkowe, jak i wspomniany kompleks Zabór. Przypomnieć należy, że na Dolnym Śląsku już majątek kilkuwioskowy traktowany był jako niezwykle okazały. I tak w odniesieniu do poszczególnych wsi obserwujemy, że od 1688 r. podziałowi na dwie, a od 1722 r. na trzy części podlegał Drzonków, którego właścicielami były rodziny Rothenburgów, Knobelsdorffów i Unruhów ${ }^{31}$. Podobny los spotkał Droszków. W 1532 r. posiadaczem pierwszego nadziału był Balzer, w 1543 r. - Hans, a w 1568 r. - Ernst von Dyhern. Druga część pozostawała na początku XV w. przy rodzinie von Rothenburgów, a następnie von Schoffów, von Burkersdorfów i von Tschammerów. Ostatecznie w 1584 r. obie części zostały włączone do kompleksu dóbr borowińskich rodziny von Kottwitzów. Dopiero w 1677 r. Ernst Heinrich von Kottwitz na Bojadłach, Konotopie i Dankowicach sprzedał Droszków hrabiemu Johannowi Heinrichowi von Dünnewaldowi na Zaborze. Rodziny von Kittlitzów, von Knobelsdorffów (później von Unruhów) posiadały wspólnie Zatonie. Podział wsi Nowy Kisielin pochodził z połowy XV w. Jedna z części pozostała w rękach Dyhernów. Do 1614 r. posiadał ją Ernst von Dyhern. Inną część posiadała rodzina von Schoffów, którą w 1565 r. sprzedała Fabianowi i Nickelowi von Tschammerom. Trzecią część w latach 1510-1587 posiadali Rothenburgowie, a od 1587 r. - Dyhernowie. Obie części Dyhernów przejęli po wojnie trzydziestoletniej Grünbergowie i tak całość funkcjonowała już do końca XVIII w. Natomiast pobliski Stary Kisielin do 1565 r. dzierżyli Burckersdorffowie, do 1591 r. - Tschammerowie, a następnie - Stentschowie. Podział miał miejsce w latach 1570-1591 i dotyczył części wsi wydzierżawionej baronowi Georgowi von Braunowi, właścicielowi Bytomia górnośląskiego.

30 Tschersich, Zur Geschichte der Orts- und Kirchengemeinde Laettnitz Kreis Günberg in Schlesien, rkps [po 1890 r.], s. 46-50.

31 A. Förster, Geschichtliches von den Dörfern des Grünberger Kreises - aus den besten vorhandenen Quellen und eigener Beobachtung und Erfahrung zusammengestellte Erinnerungsbilder, Grünberg 1905, s. 4. 
Dopiero w 1712 r. Stary Kisielin został sprzedany baronowi Balthasarowi von Stoschowi. Podział, i to trzyczęściowy, obejmował natomiast Ochlę. Górną Ochlę posiadali początkowo Knobelsdorffowie, a następnie - Dohnowie, Gersdorfowie (od 1654 r.), Unruhowie (od 1681 r.) i Nasssau (1722-1745). Ochla środkowa była własnością Rothenburgów. Dolna, trzecia część wsi pozostawała z reguły przy właścicielu części środkowej. Jednak w 1722 r. wydzielono ją Davidowi von Schwemmlerowi. Kolejną wsią, która ulegała podziałom, był Przylep. Do 1625 r. posiadali ją jej założyciele, czyli rodzina von Lesslau. Następnie część jej przejęli Landeskronowie, a rodzina von Lesslau odsprzedała w 1681 r. swoją część rodzinie von Troschków. Od 1688 r. Troschkowie posiadali już całą wieś, którą w 1722 r. zakupił Melchior von Pförtner. Podobnie wyglądała sytuacja Świdnicy należącej do Kittlitzów, której podział był uwarunkowany wewnętrznymi ustaleniami rodziny jeszcze w XVI w. ${ }^{32}$

Do wiosek, których dobra tworzyły jeden nadział od XVI do XVIII w. w weichbildzie zielonogórskim, można zaliczyć Raculę, pozostającą w rękach von Unruhów w latach 1315-1743, a także Stary Kisielin, znajdujący się po 1565 r. w posiadaniu Tschammerów, od 1712 r. - Stentschów, a od 1718 r. - Stoschów, jak również skrawki majątku nietkowskiego Rothenburgów i Łężycę oraz Słone i Buchałów, pozostające na przemian w posiadaniu Glaubitzów bądź Knobelsdorffów, dalej zaś Leśniów Wielki, Leśniów Mały, Laski, Sudoł, Radomia, Drzonów, Jany, Przytok i Zabór, znajdujące się w rękach przypuszczalnych założycieli, czyli rodziny von Tschammerów (do 1588 r.), von Dyhernów (do 1651 r.), von Montani, von Dünnewaldów (1671-1718).

Niepodzielne były, należące do majątku, Zabór-Czarna, Milsko, Łaz i Procz$\mathrm{ki}^{33}$. Dalej można wymienić Otyń Rechenbergów, a także Niedoradz, Pyrnik, Konradowo, Suchą, Klenicę, Niedoradz, Bobrowniki, Ługi, Zagórze, Płoty, Proczki, Bojadła, Konotop, pozostające w rękach Dyhernów, a od 1579 r. - Kottwitzów. Z kolei Mesze, Swarzynice, a prawdopodobnie też Mieszkowo, Bełcze, Pyrnik, Kartno, Kolsko, Lipnik, Jesionkę, Kiełpin i Letnica znajdowały się w rękach Köslitzów ${ }^{34}$.

32 O. Wolff, Geschichte der Stadt Grünberg in Niederchlesien von ihrer Entstehung bis zur Entstehung der Reformation, Grünberg 1848, s. 151-176; A. Förster, op. cit., s. 5.

33 J. Kuczer, Od glorii do upadku. Osadnictwo szlachty tytularnej na Ślasku po wojnie trzydziestoletniej na przykładzie rodziny hrabiów von Dünnewald (1669-1718), „Studia Śląskie” 2009, nr 68, s. 93-116.

34 Por. ibidem. Rozbicia majątkowe weichbildów księstwa głogowskiego obrazuje też tabela indykcji z 1726 r. zaprezentowana przez K. Orzechowskiego. Zob. Indykcja dominiów, poddanych i miast Ślaska wedlug ,pierwszej rewizji” z 1726 roku. Materiaty do statystyczno-geograficznego opisu Ślaska z pierwszej połowy XVIII wieku, wyd. K. Orzechowski, Wrocław 1995, s. 74-82. Zob. także: J. Kuczer, Szlachta w życiu społeczno-gospodarczym księstwa głogowskiego w okresie habsburskim (1526-1740), Zielona Góra 2007, s. 163-164. 


\section{WŁADZTWA (HERRSCHAFTEN)}

W tym miejscu dochodzimy do problemu istnienia kluczy majątków, których podwaliny położone zostały często przez znaczne postaci historii nie tylko Śląska, lecz także Czech czy Niemiec. Nie miały one charakteru luźnego, gdyż mogły być stanowione prawnie jako ordynacje ziemskie, podobnie jak w Rzeczypospolitej. Od czasów średniowiecza określano je mianem Herrschaften (władztwa). Co ciekawe, takie określenie na terenie Świętego Cesarstwa nadawano margrabstwom, elektoratom lub księstwom. W granicach księstwa głogowskiego istniały trzy formy wielkiej własności. Były nimi właśnie władztwa, następnie zaś dobra o charakterze zindywidualizowanym, których istnienie warunkował akt nadania królewsko-cesarskiego - na Śląsku nosiły one nazwę ,fideikomis” (Fidei-commisherrschaft). Była to formuła majątku niepodzielnego. Trzecią formą był majątek, który uzyskał status wyższy, gdyż określany jako majorat. Z takiej formy wyłoniło się nawet Wolne Państwo Stanowe (Freiestandesherrschaft) Siedlisko-Bytom Odrzański (Carolath-Beuthen), majątek „na miarę książęcą" ${ }^{35}$.

Pierwszym znanym dziś wielkim majątkiem, który należy zaliczyć do pierwszej kategorii, było wspomniane już Nowe Miasteczko, nadane w 1386 r. Lutoldowi i Johannesowi Wirsingom. Książę umożliwił im nabycie tego miasta wraz z siedmioma wsiami położonymi w weichbildzie kożuchowskim. Kolejny znaczący klucz dóbr stworzyli Rechenbergowie, którzy w 1381 r. otrzymali królewską część Bytomia Odrzańskiego i Tarnowa. Twórcą scentralizowanego majątku był jednak dopiero Melchior II, zmarły w $1485 \mathrm{r}^{36}$ Domena rodowa obejmowała niemal cały obszar późniejszego weichbildu kożuchowskiego. W jego skład wchodziło również lenno zamkowe (Burglehen Freystadt) pozyskane dla rodu przez Hansa von Rechenberga. Uzyskał on je na mocy listu żelaznego z rąk Ludwika Jagiellończyka, króla czeskiego i węgierskiego, w 1520 (1522) r. Już na początku nowej ery Rechenbergowie dysponowali więc aż 6 miastami i miasteczkami (Städtel) oraz 24 wsiami $^{37}$. Od 1507 r. przyznane było im prawo wójtowskie w Bytomiu Odrzańskim, a od lat 1506-1508 - w Sławie. Według Freibriefu z 6 stycznia 1508 r., wydanego przez Władysława Jagiellończyka, w ich dziedzicznym posiadaniu znalazły się ponadto: Gołaszyn, Lubogoszcz, część Nowego Miasteczka, a także Tarnów, Popęszyce, Siedlisko, Dębina (lub Dąb), Lipina, Przemków,

35 Fideikomis i majorat w zasadzie są zbieżnymi formami organizacji własności ziemskiej. Wyszczególnienie obu form nasunęła analiza metryki ziemskiej z 1681 r., w której spośród fideikomisów księstwa dokładnie wyodrębniono majorat Schönaichów. Zob. APW, Księstwo głogowskie 1329-1886, sygn. 513, Rubrika 10; J. Kuczer, W. Strzyżewski, Spisy dóbr księstwa głogowskiego z lat 1671-1727, Warszawa 2007, s. 102.

36 CDS, Bd. 28, s. 33, nr 113, Bd. 24, s. 105.

37 Lehns- und Besitzurkunde Schlesiens und seiner einzelnen Fürstentümer, hrsg. von C. Grünhagen, H. Markgraf, Bd. 1, Leipzig 1881, s. 195. 
Borów, Cieniawa, Wrociszów, Krępa. W 1516 r. za bezzwrotną pożyczkę 7000 guldenów węgierskich oddano im majątek Otyń wraz ze wsiami: Konradowo, Zakęcie, Bożnów, Klenica, Sucha, Niedoradz, Czarna, Bobrowniki, jak również czwartą część Koserza i Modrzycy ${ }^{38}$. Wyjątkiem było wydzielenie uczynione dla Melchiora von Gersdorfa - na czas jego życia - Gołaszyna, Nowego Miasteczka i Popęszyc, które następnie wróciły do Rechenbergów. Majątek otyński po śmierci Hansa von Rechenberga w 1540 r. przejęli jego bracia stryjeczni: Nowe Miasteczko - Georg von Rechenberg z Borowa, Sławę - Klemens, a Siedlisko-Bytom Odrzański - Melchior i Franz von Rechenbergowie (bratankowie). W 1553 r. do wydzielonego majątku borowskiego należały Nowe Miasteczko, Gołaszyn, Popęszyce, a także wspomniane nadziały Modrzycy i Koserza, które kupił po śmierci Georga w 1552 r. jego wnuk Hans. W 1579 r. ów Hans von Rechenberg odkupił jeszcze od Haugwitzów całość Nowego Miasteczka za sumę 15 tys. rtl. ${ }^{39}$

Majątek Rechenbergów posiadał analogiczny do średniowiecznego status władztwa pozostający w posiadaniu barona (Herr, później Freiherr). Wyróżnionych tym statusem dóbr było więcej w księstwie głogowskim. Choć nie musiały być tak rozległe, to ich właściciele powoli pozyskiwali dla siebie tytuły baronów, a nawet hrabiów. W tym miejscu należy przytoczyć majątki skupione wokół takich miejscowości, jak: Bojadła, Konotop i Chobienia Kottwitzów, Zabór Tschammerów i Dünnewaldów, Stary Kisielin Stoschów, rozciągający się na wsie położone w weichbildach zielonogórskim i kożuchowskim, a także leżący w księstwach jaworskim i krośnieńskim majątek Rothenburgów ${ }^{40}$, Przytok Stentschów, wspomniany Przemków Rechenbergów, a następnie rodziny von Rederów, Miłaków w weichbildzie szprotawskim, Górne i Dolne Pobrzeże Kalckreuthów oraz Mirocin Górny Dyhernów, Laski Odrzańskie i Ochlę Kobelsdorfów, Świdnicę i Małomice Kittlizów, Kamionę w weichbildzie głogowskim Lüttwitzów czy posiadłości Kalckreuthów i Dohnów w weichbildzie górowskim. W pierwszej połowie XVIII w. największymi majątkami były dobra sławskie Johanna Wentzela von Barwitza, barona Fernemont. W skład tego majątku wchodziła Sława i 15 wsi: Cegłówka, Gola Wąsoska, Jeziorna, Dębina, Lubiatów, Lubogoszcz, Myszyniec, Potrzebowo Górne, Przybyszów, Tarnawka, Wojsławice, Sławęcice oraz Krampen, Rädichen, Sperlingswinkel ${ }^{41}$. Zbliżone pod względem wielkości

38 CDS, t. 24, s. 81, nr 64 oraz s. 102, nr 6; Lehns- und Besitzurkunde Schlesiens..., s. 195; F. Minsberg, op. cit., przypis na s. 14; Aßmann, Kurze Geschichte der Stadt Deutsch-Wartenberg, 1904, s. 4.

39 J. Kuczer, Szlachta w życiu społeczno-gospodarczym ...; O. Wolff, op. cit., s. 175; E. Kolbe, op. cit., s. 48.

${ }^{40}$ W jego skład w 1718 r. wchodziły dwa miasta (Czerwieńsk i Bytnica), 10 wsi (Nietków, Nietkowice, Stara Bytnica, Nowa Bytnica, Głębowie, Drzewica, Dobrosułów, Struga, Pliszka i Pomorsko). Zob. K. Bartkiewicz, Szlachta pogranicza śląsko-lubuskiego w okresie wczesnonowożytnym (XVI-XVIII wiek), ,Rocznik Lubuski” 2000, t. 26, cz. 2, s. 18.

${ }_{41}$ Por. M. Konopnicka-Szatarska, Stawa w okresie wczesnonowożytnym (XVI-XVIII w.), [w:] Stawa. Zarys dziejów, red. W. Strzyżewski, Sława 2004, s. 71-73. 
były dobra przemkowskie Christopha Georga von Proßkaua. Składały się one z Przemkowa i 11 wsi. Wśród nich można wymienić: Szklarki, Jędrzychówek, Karpie, Krępą, Łężce, Wysokie, Rozwadów, Piotrowice, Młynów, Wilkocin oraz Fitke. Za życia Heinricha Johanna von Dünnewalda i jego synów - Franza i Ludwiga (1669-1718) - jedno z większych dóbr stanowił majątek Zabór. Składał się on z miasteczka i 10 wsi: Czarna, Milsko, Droszków, Łaz, Proczki, traktowane z osobna Dolna i Górna Tarnawa oraz dzierżawione Jesiona, Kolsko i Pyrnik. Hrabia von Reder posiadał natomiast Małomice, Dolną i Górną Iławę, Janowiec, Pruszków, Chichy, Lubiechów, Iławkę, Polkowiczki i Śliwnik (miasto i 9 wsi) ${ }^{42}$. Do większych należał też majątek barona Ferdinanda Johanna von Müllenau (Kolsko i 6 wsi: Jaczów, Jesiona, Krążkowo, Lipnik, Runów, Stypułów). Cztery pięciowioskowe majątki należały odpowiednio do hrabiego Rzeszy Johanna Friedricha d'Hautois le Bronne'a na Szklarach Górnych, Davida Heindricha von Kottwitza na Chełmku, Balthasara Friedricha von Lüttwitza na Długich oraz Adama Melchiora von Lestwitza na Czerninie. Nie każdy baron musiał posiadać w księstwie dobra dziedziczne. Na przykład baron Johann Heinrich von Dünnewald majątek Zabór w latach 1669-1772 posiadał jako trzyletnią dzierżawę, nad którą nadzór sprawowała Kamera Królewska, paradoksalnie dokonująca regularnych potwierdzeń prawa do spadku braciom von Dyhern ${ }^{43}$. Dopiero w 1678 (1679) r. Dünnewaldowi przyznano prawa do użytkowania lennego, a w latach 1692-1694 rozciągnięto ten przywilej na jego rodzinę ${ }^{44}$.

\section{FIDEIKOMISY}

O ile nie wszystkie władztwa były fideikomisami, o tyle wszystkie fideikomisy były władztwami. Fideikomisy, majoraty, a następnie - znane dopiero od czasów Jagiellonów - wolne państwa stanowe (Freiestandesherrschaften) były nowymi formami własnościowymi majątków. Fideikomis (fidei commissum 'oddane w wierne ręce'), powszechny w Niemczech od XVII w., był rozwiązaniem prawnym, według którego własność ziemska stawała się niepodzielna i pozostawała w rękach tylko jednej rodziny, bez możliwości partykularnego rozporzą-

42 APW, Księstwo głogowskie 1329-1886, sygn. 527. Majątek przemkowski uległ widocznemu powiększeniu w porównaniu ze stanem z 1508 r., kiedy to jego skład został potwierdzony Rechenbergom. Zob. CDS, t. 24, s. 108. Por. szerzej: J. Kuczer, Między prowincja a uniwersalizmem stanowym. Szlachta weichbildu zielonogórskiego w okresie 1526-1740, [w:] Zielona Góra Chociebuż. Historia społeczeństw i gospodarki, red. G. Bayerl, L. Belzyt, t. 1, Zielona Góra 2008, s. $13-45$.

43 Rodzina von Dyhernów była wcześniejszym posiadaczem Zaboru. Zob. APZG, Majątek Zabór, sygn. 18-20 i 22, s. 37.

44 Ibidem, sygn. 27, 31, 33; APW, Personalia, nobilitacje, inkolaty, tabele lenników, Rep. 47, sygn. 9, s. 28; J. Kuczer, Baronowie, hrabiowie, ksiązęta. Nowe elity Śląska, Zielona Góra 2013, s. 195; idem, Od glorii do upadku..., s. 93-116. 
dzenia nią przez aktualnych spadkobierców. Jej dziedziczenie możliwe było wyłącznie w ramach jednego domu czy linii danej rodziny, a sposób, w jaki się to odbywało, mógł być ustalony przez samego fundatora. Zmiana statusu wymagała potwierdzenia cesarskiego ${ }^{45}$.

Majątki te nie musiały być obszerne. Według metryki z 1681 r. na terenie księstwa głogowskiego istniały cztery majątki zorganizowane w fideikomisy familijne. Pierwszym był fideikomis Niebelschützów. Należały do niego wsie położone w weichbildzie głogowskim: Lipinki, Merzdorf i Glinica ${ }^{46}$. Drugim fideikomisem były dobra Georga von Berga z centrami w Kłodzie i Żukowicach w tym samym weichbildzie. Został on utworzony przez zmarłego bezpotomnie Joachima Władysława (syna Johanna) w 1597 r., a pierwszym ordynatem majątku był Christoph Georg von Berge. W 1601 r. Joachim uzyskał jego potwierdzenie od cesarza Rudolfa II. W tym przypadku majątek był dziedziczony przez najstarszego przedstawiciela linii baronowskiej bądź hrabiowskiej ${ }^{47}$. Trzeci fideikomis utworzono w weichbildzie świebodzińskim, a należał on do Kaspara von Schlichtinga. W jego skład weszła jedynie Rzeczyca.

Co istotne, fideikomisy mogły być cząstkami rozleglejszych majątków. Na przykład dobra Schlichtingów, w których skład wchodził również wzmiankowany fideikomis, obejmowały w różnym czasie, w całości bądź częściowo, Gryżynę, Łochowo, Radowice, Bucze, Jeziory, Lubinicko, Myszęcin, Ojerzyce, Staropole oraz Toporów i Kunowiczki w weichbildzie krośnieńskim ${ }^{48}$.

Fideikomisy wchodziły samoistnie w skład władztw, lecz - jak już wspomniano - władztwa nie stawały się automatycznie fideikomisami. W końcu XVII w. odnotowano czwarty fideikomis Johanna Baptysty von Barwitza, barona von Fernemont (ordynata w latach 1683-1722). W jego składzie znajdowały się wówczas opisane wyżej dobra sławskie ${ }^{49}$.

45 Fideikomisy tworzone były w oparciu o wzór hiszpańskiego majoratu. Zob. W. Seelmann, O. Klässel, Das Recht der Familienfideikommise und anderen Familiengüter, Berlin 1920; Grosses vollständiges Universal Lexicon Aller Wissenschaften und Kunste..., Bd. 9, s. 818-819; Der Große Brockhaus, Handbuch des Wissens in Zwanzig Bänden, Bd. 6, Leipzig 1930, s. 218.

46 Fideikomis Niebelschützów prowadzony był przez dwie osoby - Balthasara (Lipinki, Merzdorf) i Hansa Ernsta (Glinica). Por. APW, Księstwo głogowskie, sygn. 513, Rubrika 10, s. 47.

47 R. Sękowski, Herbarz szlachty śląskiej. Informator genealogiczno-heraldyczny, t. 1, Katowice 2002-2005, s. 159; J.K. Keller, Joachim von Berge und seine Stiftungen. Ein wichtiger Beitrag zur Geschichte Schlesiens, Glogau 1834, s. 57.

48 APW, Księstwo głogowskie, Rep. 24, sygn. 513, Rubrika 10.

49 Drugim ordynatem w latach $1722-1740$ był Johann Franz. Informator genealogiczny podaje, że fideikomis obejmował jedynie Przybyszów, Dębinę, Jeziorną, Myszyniec, Cegłówkę i Tarnawkę. Zob. R. Sękowski, op. cit., t. 3, s. 160. Wiadomość o fideikomisie sławskim znajdujemy też w Kodeksie Dyplomatycznym Śląska (CDS, t. 24, s. 155). 


\section{MAJORAT I WOLNE PAŃSTWO STANOWE}

Cechą wspólną fideikomisów i majoratów była ich niepodzielność, opierająca się na primogenituralnej zasadzie dziedziczenia. W związku z tym każdy majorat był zarazem fideikomisem, ale nie każdy fideikomis był majoratem. Prawnym spadkobiercą był wyłącznie jeden z potomków dziedzica. Ich istnienie nasuwa pewną analogię ze znanymi w Polsce ordynacjami ziemskimi. Majorat był kompleksem dóbr pozostających pod wspólną, aczkolwiek pośrednią administracją całej rodziny i działał na podstawie specjalnego statutu określającego podstawy jego funkcjonowania. Dotyczyło to głównie niepodzielności majoratu i procedur utrudniających, a nawet uniemożliwiających jego sprzedaż. Dla działań mogących naruszyć rodzinny stan posiadania wymagana była zgoda starszyzny rodowej. Ponadto dóbr tych bez zgody cesarza nie można było obciążać hipotekami w przypadku zadłużenia ich właścicieli, co prowadziło do zabezpieczenia majątkowej sytuacji rodziny ${ }^{50}$. Gromadzenie dóbr jedynego w księstwie głogowskim majoratu zapoczątkował w 1561 r. Fabian von Schönaich, który za zdobyte podczas wypraw wojennych fundusze (50 tys. rtl.) kupił od Franza von Rechenberga rozległe dobra z Bytomiem Odrzańskim, Siedliskiem i Tarnowem Jeziernym ${ }^{51}$. Po nim majątek przejął jego kuzyn Georg. Powstały w 1601 r. majorat obejmował Siedlisko (zamek i wioskę), Bytom Odrzański, Starą i Nową Bielawę, Stare i Nowe Grochowice, Nowy i Stary Tarnów, Dąbrowno, Lipiny, Borowiec, Lipno, Różanówkę, Piękne Kąty, Bycz, Miłaków, Żuków, Bukowiec, Runów, Drogomil, Konin i część wsi Gościszowice oraz Pfaffendorf. Alodium opatrzone było prawem do sądów niższych i wyższych i był to największy majątek w księstwie ${ }^{52}$. Z kolei majorat z dniem 14 listopada 1697 r. stał się wolnym państwem stanowym, co wyłączyło dobra rodziny z ogólnych struktur terytorialnych i politycznych księstwa. Było to jedynie preludium dla utworzenia z jego ziem w 1741 r. odrębnego księstwa, które (z pewnymi odchyleniami) zamknięte było w granicach pierwotnego weichbildu bytomskiego ${ }^{53}$.

${ }^{50}$ Ch. Brachvogel, op. cit., Bd. 5, s. 1596-1597.

51 APW, Stowarzyszenie Szlachty Niemieckiej (dalej: SSN), sygn. 430, s. 47-50 i 95-109.

${ }_{52}$ Metryka ziemska z 1681 r. podawała, że do majoratu należało 19 wsi (APW, Księstwo głogowskie, Rep. 24, sygn. Rubrika 10, s. 47). O powstaniu wolnego państwa stanowego zob. APW, SSN, sygn. 529, s. 50; ÖS, FHA, Böhmische Gedenkbücher, Bd. 25, s. 34; Indykcja dominiów, poddanych i miast Ślaska..., s. 160-161; H.L. Gude, op. cit., s. 846-847. Zabór wszedł w skład dóbr Schönaichów dopiero w 1783 r. Zob. E. Clauss, Führer durch Grünberg in Schlesien und seine nähere Umgebung, Grünberg 1928, s. 75; C.D. Klopsch, Geschichte des Geschlechts von Schönaich, Bd. 3, Glogau 1853, s. 1-6 i 18.

53 Sammlung der wichtigsten und nöthigsten, bisher aber noch nicht herausgegebenen Kayser- und Königl. Auch Hertzogl., Privilegien, Statuten, Rescripten... des Landes Schlesien, Bd. 2, Breslau-Crossen 1736-1739, s. 123-125; ÖS, Haus- Hof- und Staatsarchiv (dalej: HHSA), Staatenabteilungen: Ost- und Südeuropa AB VIII/7/4, Schlesien Ad. I/2, Krt. 4, Faz. 8, s. 127; APW, Personalia, nobilitacje, inkolaty, tabele lenników, Rep. 47, sygn. 8, s. 19. 
W majoratach obowiązywała podobna zasada dziedziczenia, jak w fideikomisach. Spuściznę przejmowali najpierw synowie i wnuki zmarłego, a następnie - również według starszeństwa braci - kolejne domy. Dalej prawo do schedy mieli pozostali najbliżsi krewni zmarłego. Po najstarszym, bezdzietnym bracie pierwszeństwo mieli więc kuzyni i wnuki kolejnego brata, co stawiało ich w pierwszeństwie wobec trzeciego brata i jego ewentualnymi spadkobiercami ${ }^{54}$. Tak miało przebiegać dziedziczenie aż do wyczerpania następnych domów, przy czym w majoracie Bytom-Siedlisko rozumiano wszystkie śląsko-łużyckie domy rodziny Schönaichów, a Carolath był tylko jednym z nich. Majorat bytomski stanowił więc część całości, jaką dzierżyła rodzina. Respektując powyższe zasady, 8 lutego 1610 r. zawarto tzw. układ rodzinny domu Schönaichów, zatwierdzony 17 lutego 1612 r. przez Hieronima, Jacoba, Kaspara, Hansa Georga, Fabiana i Johanna Georga von Schönaichów. Podobny Familienvertrag uzgodniono jeszcze w 1618 r. Ich twórcom przyświecał cel równego podziału dóbr, bez szkody dla członków rodzin. Miało temu służyć wspieranie podupadłych członków rodu, których wyposażano nawet częścią dochodów z posiadanych przez rodzinę dóbr. $\mathrm{O}$ wszystkim decydowała starszyzna rodziny. W skład takiego gremium po śmierci Georga weszli Fabian, Jacob, Hieronimus, Hans i Sebastian (dwaj ostatni z legatami). Do decyzji uprawniona była wybierana spośród nich „głowa rodziny”. Po wygaśnięciu ciągłości danego „domu” dobra powracały jakoby do punktu wyjścia i były przydzielane zgodnie z prawem rodzinnym oraz indywidualnymi uzgodnieniami w jego ramach. Warunkiem podstawowym było zachowanie familii przy aktualnym stanie posiadania, bez dopuszczania do dziedziczenia obcych rodzin. Nie zawsze jednak możliwe było zaspokojenie aspiracji wszystkich członków rodziny. W 1697 r., gdy Hans Georg przejmował Siedlisko jako wolne państwo stanowe, Franz Leopold - majątek Gębice, a Adam Friedrich - Młynnicę, wypłaty z części dochodów otrzymali Hans Gottlob i Carl Albrecht. Odkupienie od nich praw kosztowało wówczas 42 tys. rtl. Występowały też liczne spory, jak np. ten z 1759 r., w którym przeciw hrabiemu Hansowi Carlowi (synowi barona Hansa Georga) stanął Georg Phillip (syn Franza Leopolda), dążąc do wydziedziczenia tego pierwszego z przejętych przez Fürsta dóbr Młynnica. Nie zawsze jednak trzymano się tych postanowień, czyniono od nich bowiem często ustępstwa ${ }^{55}$.

Na wolne państwa stanowe składały się wydzielone części ziem księstw śląskich. Ich właściciele nie byli równi w prawach książętom, ponieważ wywodzili się z niższej szlachty. Co więcej, wolne państwa stanowe nie były obszarowo równe innym księstwom śląskim. Ponieważ ich właściciele pod swoim władaniem gromadzili licznie szlachtę, to sami stali się indywidualną grupą na sejmie

54 Grosses vollständiges..., Bd. 20, s. 630.

55 C.F. Michaelis, op. cit., s. 10-13, 23, 27, 41; N. Henelius, op. cit., Cap. VII, s. 36. 
śląskim ${ }^{56}$. Bytom-Siedlisko był jedynym wolnym państwem stanowym wyodrębnionym z księstwa głogowskiego. Do końca epoki habsburskiej nie posiadał jednak partykularnego prawodawstwa. Jedyny znany prawodawstwu przyszłego księstwa statut pochodzi z drugiej połowy XVII w. Został wydany przez właściciela wolnego państwa stanowego Hansa von Schönaicha w dniu 10 maja 1662 r. dla Bytomia Odrzańskiego i był potwierdzany przez jego następców. Ostatni raz miało to miejsce w 1730 r. Najprawdopodobniej Schönaichom nie przysługiwało prawo do ustanawiania indywidualnych reguł prawnych, a ewentualne statuty o charakterze ustawodawczo-justycjalnym nie mogły być uprawomocniane ani nawet rejestrowane przez Kamerę Śląską. Wydaje się, że zadaniem wspomnianego statutu było raczej usankcjonowanie i pewnego rodzaju skodyfikowanie $\mathrm{i}$ tak już istniejącego $\mathrm{w}$ formie ustnej prawa obyczajowego na terenie majoratu. Świadczyły o tym meldunki sądów okręgowych w Bytomiu i Siedlisku, których przedmiotem były wyłącznie kwestie małżeńskie i spadkowe ${ }^{57}$.

W skład majątków szlachty księstwa głogowskiego wchodziły niejednokrotnie dobra lub pojedyncze wioski położone poza jego granicami administracyjnymi. Można zaobserwować też sytuację odwrotną. Poszczególne wsie księstwa głogowskiego przynależały do majątków, których centra znajdowały się na terenie innych księstw. Przykładami mogą być: rodzina von Troschków, która posiadała majątek zarówno w okręgu sulechowskim, jak i świebodzińskim; rodzina von Rothenburgów, posiadająca majątki w księstwach głogowskim, krośnieńskim i jaworskim ${ }^{58}$; głogowscy baronowie von Stoschowie, którzy posiadali dobra w księstwie wołowskim. Fabian von Schönaich, jako starosta księstwa żagańskiego, przejął po Bibersteinach za 60 tys. rtl. majątek Mużaków, a w 1568 r. nabył grunty Eselsberg; ewenementem było sprawowanie przez tę rodzinę kontroli we władztwie Prochowice ${ }^{59}$. Okresem terytorialnego rozkwitu rodziny był przełom XVI i XVII w. Trzej wnukowie Filipa, stryja Fabiana, a synowie Johannesa, pozostawali na władztwach: Georg (zm. 1618 r.) - baron na Siedlisku; Sebastian I (zm. 1603 r.) - pan na Młynnicy; Johann Georg (zm. 1619 r.) - pan na Gębicach. Również Bergowie, oprócz dóbr senioralnych, posiadali wiele majątków: Gozdnicę koło Żagania, Borowe i Nową Jabłonę koło Szprotawy, Lipę i zamek Świny koło Jawora, Pakoszów koło Jeleniej Góry, Radziechów nieopodal Złotoryi, Rosochatą w księstwie legnickim, Węgrzyce w księstwie wołowskim, Trzęsów w księstwie głogowskim, Kotowice koło Kożuchowa ${ }^{60}$.

56 F.W. Pachaly, Sammlung verschiedner Schriften über Schlesiens Geschichte und Verfassung, Bd. 1, Breslau 1790, s. 319-320.

57 A. Wentzel, Das jetzt bestehende Provinziel-Reche des Herzogtums Schlesien und der Grafschaft Glatz, Breslau 1839, s. 423.

58 APW, Dep. rodzinne: von Rothenburg, Rep. 132d, sygn. 26, 27, 28.

59 H. Knothe, Geschichte des Oberlausitzer Adels und seiner Güter vom XIII. bis gegen Ende des XVI. Jahrhunderts, Leipzig 1879, s. 482; W. Barth, op. cit., s. 16.

${ }_{60}$ R. Sękowski, op. cit., t. 1, s. 159. 


\section{PODSUMOWANIE}

Analiza struktury własności ziemskiej księstwa głogowskiego pod panowaniem rządów habsburskich przynosi interesujące wyniki. Oto bowiem na obszarze jednej z szesnastu jednostek administracyjnych, jakimi były księstwa, obserwujemy z jednej strony nasilone rozdrobnienie własności ziemskiej, a z drugiej - udane starania o koncentrację schedy. Nie było to zwyczajem, lecz dość często większe majątki ziemskie w swych rękach skupiały rody tytularne, baronowie czescy, baronowie Rzeszy, hrabiowie czescy, hrabiowie Rzeszy. Podsumowując, można zauważyć, że podziały dóbr ziemskich miały proces trwały, natomiast tworzenie wielkich dóbr rodowych przebiegało w dwóch okresach. Pierwszym z nich był wiek XVI, a drugim - okres po wojnie trzydziestoletniej, kiedy na Śląsku pojawili się generałowie i urzędnicy królewsko-cesarscy, którzy niejednokrotnie - jak Fernemontowie, Dünnewaldowie, Pachtowie, Sintzendorfowie - w zamian za wysokie sumy bądź wcześniej poczynione na rzecz skarbu cesarskiego pożyczki wchodzili w posiadanie dóbr wielowioskowych. Co ciekawe, pozyskanie dla siebie takiego majątku często było związane z uzyskaniem tytułu szlacheckiego.

Wszystkie prawa do ziemi na terenie księstwa głogowskiego wywodziły się zarówno ze średniowiecznych zasad lennych, jak i ze stanowionego w przyszłości prawa ziemskiego spisanego przez P. Weltzky'ego von Petersheide'a ${ }^{61}$. Rozpatrując omawiany obszar, można odnotować, że własność szlachecka koncentrowana była jako tzw. własność rycerska (Rittergütter), a następnie mogła przechodzić stadia „wyższe”, którymi były tzw. władztwa (Herrschaften), fideikomisy (ordynacje zwykłe), majoraty (ordynacje z przypisanymi do nich specjalnymi prawami publicznymi) oraz wolne państwa stanowe - było nim Wolne Państwo Stanowe Siedlisko-Bytom Odrzański. To ostatnie było jednym z sześciu tego typu tworów administracyjnych na Śląsku, obok Milicza, Żmigrodu, Pszczyny, Sycowa i Bytomia Górnośląskiego. Były to majątki, których właściciele z końcem periody habsburskiej tytułowali się głównie jako hrabiowie Rzeszy. Warto jeszcze wspomnieć, że ich pozycja publicznoprawna równa była pozycji książąt z dynastii Wirtembergów, Auerspergów, Lobkowitzów czy Lichtensteinów.

Struktura ziemska, jaką obserwujemy w okresie wyznaczonym przez lata 1526 i 1740, jest charakterystyczna dla Dolnego Śląska. Podobnie kształtowała się ona na obszarze księstw brzeskiego, legnickiego, jaworsko-świdnickiego czy ziębickiego ${ }^{62}$. Na Górnym Śląsku, zwłaszcza w dominującym tam księstwie

${ }^{61}$ Por. P. Weltzky von Petersheide, Kurtzer Tractat und Bericht von dem Schlesischen Ritterrecht und Ehrengericht denen vom Adel und Ritterstandt, Leipzig 1615.

62 Zob. np. J. Kuczer, Spis lenników księstwa żagańskiego z 1719 roku, „Studia Zachodnie” 2008, nr 10, s. 187-194; idem, Spis właścicieli dóbr ziemskich księstwa świdnicko-jaworskiego z 1690 roku, „Studia Zachodnie” 2009, nr 11, s. 175-189; J. Kuczer, M. Maciejewski, Szlachta 
opolsko-raciborskim, istniały wielkie domeny ziemskie, natomiast własność rozdrobniona była zepchnięta na margines. Było to związane z odmiennością tradycji oraz bliskością ziem polskich i prawa morawskiego. Dolny Śląsk od połowy XIII w. ulegał silnej dominacji żywiołu rycerstwa niemieckiego, które przyniosło ze sobą wzorce zgoła odmienne. Wyróżniające się w tym względzie było zwłaszcza istnienie trzech rodzajów posiadania ziemi, mianowicie prawo alodialne, prawo lenne i prawo lenne o cechach alodiów. Pierwsze z nich było prawem tzw. polskim, dziedziczonym bezwarunkowo i podległym czudom, czyli sądom prawa polskiego. Drugie było przyznawane na prawie lennym, wymagającym każdorazowego potwierdzenia królewskiego o cesji na rzecz kolejnej osoby; podlegało ono sądownictwu księcia reprezentowanego przez starostę księstwa. Ostatni rodzaj dóbr był modelem łączonym - polegał on wprawdzie na dziedziczności bezwarunkowej, lecz podległość sądownicza właściciela nadal pozostawała przy sądzie książęcym.

\section{BIBLIOGRAFIA}

\section{Źródła}

Archiwum Państwowe w Zielonej Górze, Majątek Zabór, sygn. 8, 18-20 i 22, 27, 31, 33.

Archiwum Państwowe we Wrocławiu:

- Dep. rodzinne: von Rothenburg, Rep. 132d, sygn. 26, 27, 28,

- Księstwo głogowskie 1329-1886, Rep. 24, sygn. 135, 155, 382, 513, 527,

- Personalia, nobilitacje, inkolaty, tabele lenników, Rep. 47, sygn. 8, 9,

- Stowarzyszenie Szlachty Niemieckiej, sygn 430, 529.

Codex Diplomaticus Silesiae, t. 24, 28.

Österreichisches Staatsarchiv, Finanz- und Hofkammer Archiv:

- Böhmische Gedenkbücher, Bd. 25, 31,

- Familien-Akten, B/P 442, C/K 1-19, 263 i 264, D-T 176, D 81, G 190, H - 22 i 44, L 86, R 44, S 54, 185, 195, 308 i 384, Z 18.

Österreichisches Staatsarchiv, Haus- Hof- und Staatsarchiv, Staatenabteilungen, Ost- und Südeuropa AB VIII/7/4, Schlesien Ad. I/2, Krt. 4, Faz. 8.

\section{Literatura}

Aßmann, Kurze Geschichte der Stadt Deutsch-Wartenberg, 1904.

Aubin H., Geschichte Schlesiens, Bd. 1, Breslau 1938.

Bahlcke J., Regionalismus und Staatsintegration im Widerstreit. Die Länder der böhmischen Krone in ersten Jahrhundert der Habsburgerherrschaft (1526-1619), Mümchen 1994.

Barth W., Die Familie von Schönaich und die Reformation, Beuthen 1891.

Bartkiewicz K., Szlachta pogranicza śląsko-lubuskiego w okresie wczesnonowożytnym (XVI-XVIII wiek), „Rocznik Lubuski” 2000, t. 26, cz. 2.

Brachvogel Ch., Continuation derer Käyser- und Königlichen Privilegien, Statuten und Sanctionum Pragmaticum Des Landes Schlesien..., Bd. 3, 5, 6, Breslau 1717-1730.

Clauss E., Führer durch Grünberg in Schlesien und seine nähere Umgebung, Grünberg 1928.

Księstwa Legnickiego w drugiej połowie XVII w. w świetle spisu dóbr ziemskich z 1676 r., „Slezský sborník. Acta Silesiaca" 2016, nr 1, s. 5-28. 
Der Große Brockhaus, Handbuch des Wissens in Zwanzig Bänden, Bd. 6, Leipzig 1930.

Dziewulski W., Nowe dane statystyczne o ludności miast $i$ wsi Ślaska w XVI w., „Śląski Kwartalnik Historyczny Sobótka" 1975, nr 30.

Dziewulski W., Zaludnienie Śląska w końcu XVI w. i na początku XVII w., „Przegląd Zachodni” 1952, $\mathrm{nr} 8$.

Förster A., Geschichtliches von den Dörfern des Grünberger Kreises - aus den besten vorhandenen Quellen und eigener Beobachtung und Erfahrung zusammengestellte Erinnerungsbilder, Grünberg 1905.

Generalne tabele statystyczne Śląska 1787 roku, wyd. T. Ładogórski, Wrocław 1954.

Grosses vollständiges Universal Lexicon Aller Wissenschaften und Kunste..., Bd. 9, 20.

Grünhagen C., Geschichte Schlesiens, Bd. 2, Gotha 1884.

Gryphius A., Glogauisches Fürstenthumbs Landes Privilegia aus dem Originalen an tag gegeben..., Lissa 1653.

Gude H.L., Staat von Schlesien, Halle 1708.

Heck R., Uwagi o gospodarce folwarcznej, „Śląski Kwartalnik Historyczny Sobótka” 1956, nr 11.

Heller O., Der Freitädter Kreis mit besonderer Berücksichtigung des Fürstentums Carolath-Beuthen in geographisch-statistischer und geschichtlicher Beziehung, Freystadt 1844.

Henelius N., Silesiographia renovata necessariis Scholiis observationibus et indice aucta, Wratislaviae-Lipsiae 1704.

Hoffmann H., Fürst Carolath contra Glogauer Jesuiten, Ein Beitrag zur Friderizianischen Kabinettsjustiz, „Archiv für Schlesische Kirchengeschichte“ 1936, Bd. 1.

Indykcja dominiów, poddanych i miast Śląska wedtug ,pierwszej rewizji” z 1726 roku. Materiały do statystyczno-geograficznego opisu Ślaska z pierwszej połowy XVIII wieku, wyd. K. Orzechowski, Wrocław 1995.

Jokisch G., Geschichte der Stadt Neustädtel, Glogau 1866.

Jurek T., Geneza księstwa głogowskiego, „Przegląd Historyczny” 1987, nr 78.

Kaczmarczyk Z., Dzieje Ziemi Lubuskiej, „Rocznik Lubuski” 1981, t. 11, cz. 1.

Keller J.K., Joachim von Berge und seine Stiftungen. Ein wichtiger Beitrag zur Geschichte Schlesiens, Glogau 1834.

Klopsch C.D., Geschichte des Geschlechts von Schönaich, Bd. 3, Glogau 1853.

Knothe H., Geschichte des Oberlausitzer Adels und seiner Güter vom XIII. bis gegen Ende des XVI. Jahrhunderts, Leipzig 1879.

Kolbe E., Geschichte der Stadt Neustädtel, unter Benutzung amtlicher und privater Quellen bearbeitet, Neustädtel [po 1924 r.].

Konopnicka-Szatarska M., Stawa w okresie wczesnonowożytnym (XVI-XVIII w.), [w:] Stawa. Zarys dziejów, red. W. Strzyżewski, Sława 2004.

Kuczer J., Baronowie, hrabiowie, ksiązęta. Nowe elity Śląska, Zielona Góra 2013.

Kuczer J., Między prowincja a uniwersalizmem stanowym. Szlachta weichbildu zielonogórskiego w okresie 1526-1740, [w:] Zielona Góra - Chociebuz. Historia spoteczeństw i gospodarki, red. G. Bayerl, L. Belzyt, t. 1, Zielona Góra 2008.

Kuczer J., Od glorii do upadku. Osadnictwo szlachty tytularnej na Ślasku po wojnie trzydziestoletniej na przykładzie rodziny hrabiów von Dünnewald (1669-1718), „Studia Śląskie” 2009, nr 68.

Kuczer J., Spis lenników księstwa żagańskiego z 1719 roku, „Studia Zachodnie” 2008, nr 10.

Kuczer J., Spis właścicieli dóbr ziemskich księstwa świdnicko-jaworskiego z 1690 roku, „Studia Zachodnie" 2009, nr 11.

Kuczer J., Szlachta jako dzierżawca dóbr królewskich w księstwie głogowskim w XVI-XVII wieku, „Studia Lubuskie” 2007, nr 3.

Kuczer J., Szlachta w życiu społeczno-gospodarczym księstwa głogowskiego w okresie habsburskim (1526-1740), Zielona Góra 2007. 
Kuczer J., Maciejewski M., Szlachta Księstwa Legnickiego w drugiej połowie XVII w. w świetle spisu dóbr ziemskich z 1676 r., „Slezský sborník. Acta Silesiaca” 2016, nr 1.

Kuczer J., Strzyżewski W., Spisy dóbr księstwa głogowskiego z lat 1671-1727, Warszawa 2007.

Lehns- und Besitzurkunde Schlesiens und seiner einzelnen Fürstentümer, hrsg. von C. Grünhagen, H. Markgraf, Bd. 1, Leipzig 1881.

Michaelis C.F., Rechtliche und Historische Entwicklung der Verhältnisse der Lehn- und Fidei-Commis-Herrschaften Amtitz und Möllendorf und Rechte des jedesmaligen regierenden Fürsten zu Carolath-Beuthen auf dieselben, Glogau 1832.

Minsberg F., Geschichte der Stadt und Festung Gross-Glogau, Bd. 2, Glogau 1853.

Nowogrodzki S., Rzady Zygmunta Jagiellończyka na Śląsku i w Łużycach, Kraków 1937.

Pachaly F.W., Sammlung verschiedner Schriften über Schlesiens Geschichte und Verfassung, Bd. 1, Breslau 1790.

Ptak M., Lenno zamkowe Żurawina (1608-1615), „Acta Universitatis Wratislaviensis. Prawo” 2001, nr 273.

Ptak M., Zgromadzenia i urzędy księstwa głogowskiego od początku XIV w. do 1740 r., Wrocław 1991.

Sammlung der wichtigsten und nöthigsten, bisher aber noch nicht herausgegebenen Kayser- und Königl. Auch Hertzogl., Privilegien, Statuten, Rescripten ... des Landes Schlesien, Bd. 2, Breslau-Crossen 1736-1739.

Schickfuss J., New vermehrte Schlesische Chronika und Landesbeschreibung bis 1619, Jena-Breslau 1625.

Scriptores Rerum Silesiacarum, hrsg. von H. Markgraf, „Annales Glogovienses bis zum Jahr 1493 nebst urkundlichen Beilagen“ 10, Breslau 1877.

Seelmann W., Klässel O., Das Recht der Familienfideikommise und anderen Familiengüter, Berlin 1920.

Sękowski R., Herbarz szlachty śląskiej. Informator genealogiczno-heraldyczny, t. 1, 3, Katowice 2002-2005.

Sinapius J.C., Schlesien in merkantilischer, geographischer und statistischer Hinsicht, Sorau-Leipzig 1806.

Stenzel G.A., Geschichte Schlesiens, Breslau 1853.

Sternagel G., Geschichte Schlesiens, Breslau 1803.

Szczegóła H., Z dziejów księstwa głogowskiego w wiekach średnich, [w:] Ze studiów nad średniowiecznym Głogowem i Krosnem, Zielona Góra 1970.

Tschersich, Zur Geschichte der Orts- und Kirchengemeinde Laettnitz Kreis Günberg in Schlesien, rkps [po 1890 r.].

Weber M., Das Verhältnis Schlesien zum Alten Reich in Früher Neuzeit, Köln 1992.

Weltzky von Petersheide P. von, Kurtzer Tractat und Bericht von dem Schlesischen Ritterrecht und Ehrengericht denen vom Adel und Ritterstandt, Leipzig 1615.

Wentzel A., Das jetzt bestehende Provinziel-Reche des Herzogtums Schlesien und der Grafschaft Glatz, Breslau 1839.

Wojciechowski S., Ustrój polityczny Śląska, [w:] Historia Śląska od najdawniejszych czasów do roku 1400, t. 1, Kraków 1933.

Wolff O., Geschichte der Stadt Grünberg in Niederchlesien von ihrer Entstehung bis zur Entstehung der Reformation, Grünberg 1848.

Zerndt G., Geschichte von Stadt und Kreis Schwiebus, Bd. 2, Schwiebus 1909.

Zimmermann F., Bayträge zur Beschreibung von Schlesien, Bd. 10, Brieg 1791. 


\section{SUMMARY}

The article discusses the problem of land ownership in the hands of the nobility in the Habsburg period in the Duchy of Głogów, which remained a separate administrative part of the then Czech rule. The issues were mainly connected with the population potential of the principality and with its territory, on the basis of which the development of small, medium and large landed property was analyzed. The noble property of the Głogów principality was entrusted in possession on the basis of three legal orders. The main division was on the line of unconditional inheritance, feudal heredity and transitory form. At the root of such diversity was the complicated history of the Duchy of Głogów in the middle and late Middle Ages, and thus its belonging to the Czech Crown, the rule of the Głogów Piasts, and then entrusting it to the members of the Polish-Lithuanian Jagiellonian Dynasty (Jan Olbracht and Zygmunt Jagiellończyk, Władysław Jagiellończyk and Ludwik II). The discussed diversity in terms of the size of assets and their legal position vis-à-vis the King of the Czech Republic was associated with the occurrence of such forms as powers, fideicommissions, majorates and a free state. The owners of each of them had different land rights, and their estates - along with raising their rank - could even become separate administrative units whose owners could acquire princely rights (including, for example, a separate position in public life by obtaining a vote during the Silesian parliament).

Keywords: Silesia; nobility; landed property; principality of Głogów; fideicommission 